\title{
Estimation of crude fiber content in different cultivars of mango (Mangifera indica L.) grown in Telangana State, India
}

\author{
B. Soujanya , A. Kiran Kumar*, A. Bhagwan**, M. Sreedhar***, S. Vanisri**** and P. Saidaiah***** \\ College of Horticulture, Sri Konda Laxman Telangana State Horticultural, University, Rajendranagar-500030, T.S. India \\ *College of Horticulture, Sri Konda Laxman Telangana State,Horticultural University, Rajendranagar-500030, T.S. India \\ **College of Horticulture, Sri Konda Laxman Telangana State Horticultural, University, Rajendranagar-500030, T.S. India \\ ***Regional Sugarcane and Rice Research Station (RSRRS), Rudrur, PJTS Agricultural University, Rudrur-503188, T.S. India \\ ****Institute of Biotechnology, PJTS Agricultural University, Rajendranagar-500030, T.S. India \\ *****College of Horticulture, Sri Konda Laxman Telangana State, Horticultural University, Mojerla-509219, T.S. India
}

\section{Article Info}

\section{Article history}

Received 15 January 2021

Revised 6 March 2021

Accepted 7 March 2021

Published online 30 June 2021

\section{Keywords}

Mango cultivars

Crude fiber content

Antioxidants

Juicy cultivars

Table cultivars

\begin{abstract}
The experiment was carried out at the College of Horticulture, Sri Konda Laxman Telangana State Horticultural University, Rajendranagar to estimate the crude fibre content in fifty mango (Table and Juicy) cultivars. Experiment was laid out in a completely randomized design and replicated thrice during 2018-19 and 2019-20. Fruits were collected from Fruit Research Station, Sangareddy. Crude fiber content was significantly $(p<0.05)$ varied among the different mango varieties. Highest amount of crude fibre content was recorded in the Juicy cultivar Nagulapalli Iraslu (7.04 g/100 g/100 g) while lowest in Goa Bandar (3.02 g/100) during 2018-19. Same cultivars have recorded the highest amount of crude fibre content in Nagulapalli Irsalu $(6.98 \mathrm{~g} / 100 \mathrm{~g})$ while lowest in Goa Bandar $(3.17 \mathrm{~g} / 100 \mathrm{~g}) \mathrm{during}$ 2019-20. Regarding pooled data, highest crude fibre was found in Nagulapalli Iraslu $(7.01 \mathrm{~g} / 100 \mathrm{~g})$ while lowest in Goa Bandar $(3.10 \mathrm{~g} / 100 \mathrm{~g})$. Among all the cultivars, more fibre content was presented in the Juicy cultivars compared to Table cultivars. The present study which will strongly help the consumers, dietitian and processing industry policy makers.
\end{abstract}

\section{Introduction}

Mango (Mangifera indica L.) is well known for its nutritional properties and mainly cultivated in India, most of the people liked for its sweet and juicy flesh. In many regions of the world, the mango stands out for its high commercial and nutritional values, especially in the tropical regions. In India, mango is cultivated in an area of 2.31 Million ha with production of 22.35 Million tonnes and 7.3 MT/ha productivity. Major mango growing states are Uttar Pradesh, Andhra Pradesh, Odisha, Karnataka and Telangana (NHB database, 2019).

Mango is a delicious, juicy fruit, not only delicious but also rich in prebiotic dietary fibre, vitamins, minerals and polyphenolic flavonoid antioxidant compounds. Studies show that soluble fibre helps to lower blood cholesterol level, thereby reducing the risk of heart disease (Abdullahi et al. 2010). Dietary fibre is made up of a variety of compounds that are beneficial to the digestive system and also provide health benefits to other functions in the body.

Soluble fibre is also beneficial in the management of diabetes. It helps to keep blood glucose (sugar) levels balanced. Research studies

\section{Corresponding author: B. Soujanya}

Ph.D. Scholar, College of Horticulture, Sri Konda Laxman Telangana State Horticultural, University, Rajendranagar-500030, T.S. India E-mail: bsoujany129@gmail.com

Tel.: +91-9989431077

Copyright (C) 2021 Ukaaz Publications. All rights reserved.

Email: ukaaz@yahoo.com; Website: www.ukaazpublications.com indicate that insoluble fibre plays a role in the prevention of colon cancer. Since high fibre foods are filling and tend to be low in fat, both types of fibre fruits also provide an excellent source of several vitamins, minerals and antioxidants.

Studies on mango pulp showed that a high proportion of the fibre fraction consists of pectin and its content in the peel is also quite high (Berardini et al., 2005; Sirisakulwat et al., 2008). Pectin shows prebiotic effect because, it is not hydrolyzed in human's endogenous digestive enzymes but it is fermented by microflora of colon which is present in the digestive system. Its biological activities have attracted interest in the last decades, because of their postulated positive effects on health such as cholesterol-lowering, cancerpreventing, and blood glucose-regulating properties (Kim, 2010). The presence of pectin in mango pulp adds to it a functional attribute, and this point to the need for further investigation of fibre in mango pulp from different varieties. Fibre content varied from variety to variety based on utility purpose also. Based on the above nutritional facts, the study was designed to estimate the crude fibre content in fifty cultivars (thirty-six Table and fourteen Juicy) of mango, for further research in processing industries.

\section{Material and Methods}

\subsection{Sample collection}

The experimental material comprised of fifty mango cultivars (thirty-six Table and fourteen Juicy). Fruits were collected from 
the Fruit Research Station, Sangareddy, Sri Konda Laxman Telangana State Horticultural University. All fifty cultivars harvested based on their maturity standards (Brix values). The experiment was carried during 2018-19 and 2019-20. Among the fifty cultivars, Manjeera is a hybrid (Rumani x Neelum) released from FRS, Sangareddy. Dashehari-35, it is clonal selection from Dashehari developed by FRS, Sangareddy. List of fifty cultivars given in the Table 1 .

Table 1: List of Table and Juicy cultivars of mango

Cultivars of mango Juicy cultivars

\begin{tabular}{|c|c|c|}
\hline 1. & Dasehari 35 & 26. Ranitellakaya \\
\hline 2. & Allampur Baneshan & 27. Rumani \\
\hline 3. & Asif Us Samar & 28. Sannakulu \\
\hline 4. & Azam Us samar & 29. Shajahan \\
\hline 5. & Baneshan & 30. Shendriya \\
\hline 6. & Chinna Suvarnarekha & 31. Sora \\
\hline 7. & Dashehari & 32. Suvarnarekha \\
\hline 8. & Dilpasand & 33. Totapari \\
\hline 9. & Goa Bandar & 34. Vaddepalli Selection \\
\hline 10. & Himayath & 35. Vanraj \\
\hline 11. & Jahangir & 36. Yerra Mulgoa \\
\hline 12. & Kaju & 37. AryavrthamIrsalu \\
\hline 13. & Kalepahad & 38. Cherukurasam \\
\hline 14. & Kesar & 39. Chinnarasam \\
\hline 15. & Lalmuni & 40. Kothapalli Kobbari \\
\hline 16. & Latif Us Samar & 41. Meetavari Peechumanu \\
\hline 17. & Mahamooda Uppal & 42. NagulapalliIrsalu \\
\hline 18. & Mahamooda Vikarabad & 43. Navaneetham \\
\hline 19. & Manjeera & 44. Panakalu \\
\hline 20. & Mulgoa & 45. Panchavarnam \\
\hline 21. & Nazeem Pasand & 46. Pandurivari Mamidi \\
\hline 22. & Neeleshan & 47. Peddarasam \\
\hline 23. & Neelum & 48. Yellow Arati \\
\hline 24. & Parasapalli Doodiya & 49. Yerra Arati \\
\hline 25. & Pulihora & 50. Zardalu \\
\hline
\end{tabular}

\subsection{Sample preparation}

Fruits were harvested an early hour by manually to avoid any mechanical injury. Only the firm and well-developed fruits of uniform size and maturity, free from pests and diseases, injuries, bruises and blemishes were selected for the experiment. Harvested mangoes were peeled by using a knife, stone was removed and cut into pieces and then grounded into pulp. For fibre estimation, extracted pulp was dried in oven at $60^{\circ} \mathrm{C}$ for $24 \mathrm{~h}$ and powdered. Five fruits of each cultivar were taken for the experiment which were replicated thrice in both seasons (2018-19 and 2019-20) to determine the fibre content.

\subsection{Estimation of crude fibre}

The crude fibre content of the mango samples was determined by the AOAC (2000) method. $1.0 \mathrm{~g}$ of the finely ground sample of each cultivar was defatted with petroleum ether and weighed out into a round bottom flask $100 \mathrm{ml}$ of $1.25 \%$ Sulphuric acid solution was added and the mixture boiled under a reflux for $30 \mathrm{~min}$. The hot solution was quickly filtered under suction. It is then washed with boiling water until the washings are no longer acid. It was quantitatively transferred into the flask and $100 \mathrm{ml}$ of hot $1.25 \mathrm{~g}$ sodium hydroxide $(\mathrm{NaOH})$ solution was added into the flask and the contents were again boiled under reflux for 30 min and quickly filtered under suction. The soluble residue was washed with boiling water until it was base free. It was dried to constant weight in the oven at $105^{\circ} \mathrm{C}$, cooled in a desicator and weighed $(\mathrm{C} 1)$. The weighed sample (C1) was incinerated in a muffle furnace at $300^{\circ} \mathrm{C}$ for about $30 \mathrm{~min}$, cooled in the desiccator and reweighed (C2). The loss in weight of sample on incineration $=\mathrm{C} 1-\mathrm{C} 2$.

$$
\text { Crude fibre }=\frac{\mathrm{C} 1-\mathrm{C} 2}{\text { Weight of original sample }} \times 100(\mathrm{~g} / 100 \mathrm{~g})
$$

\subsection{Statistical analysis}

All the analysis was performed in triplicates and the results were presented as Mean \pm standard deviation. Differences between variables were tested for significance by one-way analysis of variance (ANOVA) using (SAS version 9.1, Statistical Analysis System Institute, Inc. Cary, NC).

\section{Results}

Crude fibre content of different mango cultivars in both seasons (2018-19 and 2019-20) and pooled data was shown in Table 2 and Figure 1 (a, b, c, d, e). A remarkable variability in crude fibre content was seen among the fifty mango cultivars. All values were found to be varied significantly $(p<0.05)$ among all the fifty mango cultivars. It is reported from the results of 2018-19, the range of crude fibre content was $3.02 \mathrm{~g} / 100$ (Goa Bandar) to $7.04 \mathrm{~g} / 100$ (Nagulapalli Irsalu). The range of crude fibre content was observed $3.17 \mathrm{~g} / 100 \mathrm{~g}$ (Goa Bandar) to $6.98 \mathrm{~g} / 100 \mathrm{~g}$ (Nagulapalli Irsalu) during the 2019-20. According to the pooled data, crude fibre ranged from $3.10 \mathrm{~g} / 100 \mathrm{~g}$ (Goa Bandar) to $7.01 \mathrm{~g} / 100$ (Nagulapalli Iraslu) (Figure 1a and 1e). 
Table 2: Crude fiber content (g/100 g) of fifty mango cultivars (Table and Juicy)

\begin{tabular}{|c|c|c|c|}
\hline \multirow{2}{*}{$\begin{array}{l}\text { Cultivars } \\
\text { Table varieties }\end{array}$} & \multicolumn{3}{|c|}{ Fibre content (g/100) } \\
\hline & 2018-19 & 2019-20 & Pooled data \\
\hline Dasehari 35 & 5.88 & 5.22 & 5.55 \\
\hline AllampurBaneshan & 4.04 & 4.12 & 4.08 \\
\hline Asif Us Samar & 4.27 & 4.38 & 4.33 \\
\hline Azam Us samar & 4.47 & 4.42 & 4.44 \\
\hline Baneshan & 3.71 & 3.91 & 3.81 \\
\hline Chinna Suvarnarekha & 4.08 & 4.24 & 4.16 \\
\hline Dashehari & 5.15 & 5.19 & 5.17 \\
\hline Dilpasand & 4.73 & 4.52 & 4.62 \\
\hline Goa Bandar & 3.02 & 3.17 & 3.10 \\
\hline Himayath & 3.12 & 3.24 & 3.18 \\
\hline Jehangir & 4.32 & 4.33 & 4.33 \\
\hline Kaju & 3.15 & 3.28 & 3.22 \\
\hline Kalepahad & 4.73 & 4.80 & 4.76 \\
\hline Kesar & 4.72 & 4.83 & 4.77 \\
\hline Lalmuni & 3.57 & 3.60 & 3.59 \\
\hline Latif Us Samar & 4.84 & 4.85 & 4.85 \\
\hline Mahamooda Uppal & 4.34 & 4.18 & 4.26 \\
\hline Mahamooda Vikarabad & 4.84 & 4.91 & 4.87 \\
\hline Manjeera & 4.83 & 4.95 & 4.89 \\
\hline Mulgoa & 4.15 & 4.28 & 4.21 \\
\hline Nazeem Pasand & 6.23 & 6.09 & 6.16 \\
\hline Neeleshan & 3.82 & 3.94 & 3.88 \\
\hline Neelum & 3.65 & 3.77 & 3.71 \\
\hline Parasapalli Doodiya & 4.25 & 4.15 & 4.20 \\
\hline Pulihora & 4.53 & 4.22 & 4.37 \\
\hline Ranitellakaya & 4.36 & 4.64 & 4.50 \\
\hline
\end{tabular}

\begin{tabular}{|c|c|c|c|}
\hline Rumani & 4.69 & 4.75 & 4.72 \\
\hline Sannakulu & 4.65 & 4.80 & 4.73 \\
\hline Shajahan & 4.46 & 4.52 & 4.49 \\
\hline Shendriya & 5.72 & 5.86 & 5.79 \\
\hline Sora & 4.16 & 4.08 & 4.12 \\
\hline Suvarnarekha & 4.26 & 4.33 & 4.29 \\
\hline Totapari & 4.82 & 4.82 & 4.82 \\
\hline Vaddepalli Selection & 4.73 & 4.61 & 4.67 \\
\hline Vanraj & 3.54 & 3.28 & 3.41 \\
\hline Yerra Mulgoa & 4.26 & 4.34 & 4.30 \\
\hline Juicy varieties & 2018-19 & 2019-20 & Pooled data \\
\hline Aryavrtham Irsalu & 5.84 & 5.72 & 5.78 \\
\hline Cherukurasam & 6.33 & 6.57 & 6.45 \\
\hline Chinnarasam & 5.54 & 5.22 & 5.38 \\
\hline Kothapalli Kobbari & 6.36 & 6.18 & 6.27 \\
\hline Meetavari Peechumanu & 5.95 & 6.02 & 5.98 \\
\hline Nagulapalli Irsalu & 7.04 & 6.98 & 7.01 \\
\hline Navaneetham & 6.13 & 6.11 & 6.12 \\
\hline Panakalu & 6.40 & 6.41 & 6.40 \\
\hline Panchavarnam & 6.18 & 6.28 & 6.23 \\
\hline Pandurivari Mamidi & 5.25 & 5.23 & 5.24 \\
\hline Peddarasam & 5.98 & 5.85 & 5.92 \\
\hline Yellow Arati & 6.85 & 6.22 & 6.53 \\
\hline Yerra Arati & 6.68 & 6.62 & 6.65 \\
\hline Zardalu & 5.82 & 5.90 & 5.86 \\
\hline Mean & 4.89 & 4.88 & 4.88 \\
\hline Mean $\pm \mathrm{SE}$ & 0.066 & 0.033 & 0.037 \\
\hline CD at $5 \%$ & 0.186 & 0.094 & 0.103 \\
\hline $\mathrm{CD}$ at $1 \%$ & 0.246 & 0.124 & 0.136 \\
\hline CV & 2.346 & 1.185 & 1.860 \\
\hline
\end{tabular}

(Values are Mean \pm SD values of three replicates, $(p \leq 0.05$ ) 


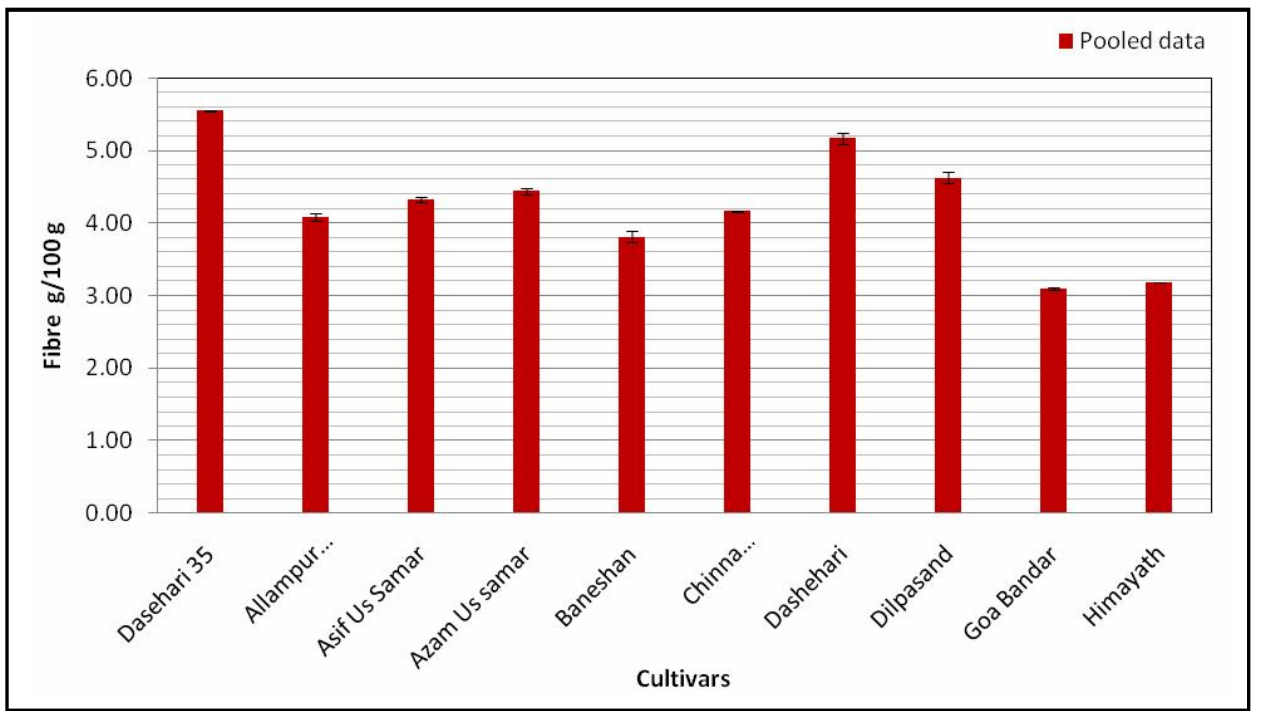

Figure 1(a): Crude fiber content (g/100 g) of ten mango (Table) cultivars.

(Values are Mean \pm SD values of three replicates, $(p \leq 0.05$, vertical bars indicate the error)

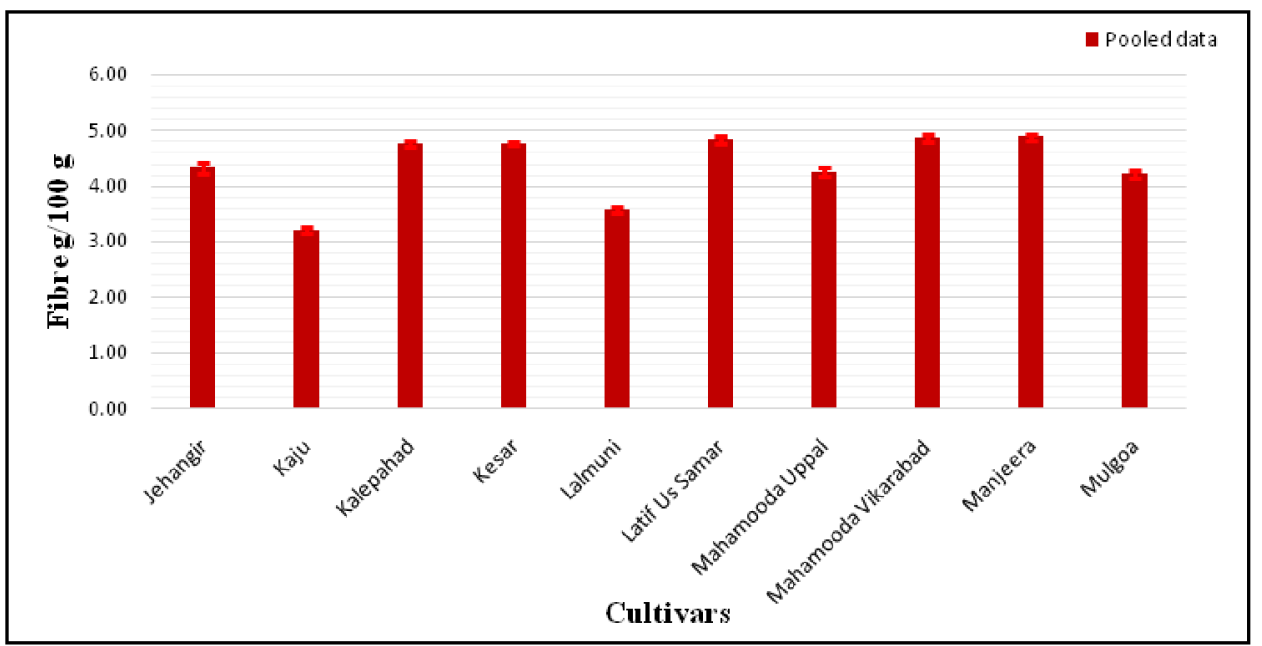

Figure 1(b): Crude fiber content (g/100 g) of ten mango (Table) cultivars.

(Values are Mean \pm SD values of three replicates, $(\boldsymbol{p} \leq \mathbf{0 . 0 5}$, vertical bars indicate the error)

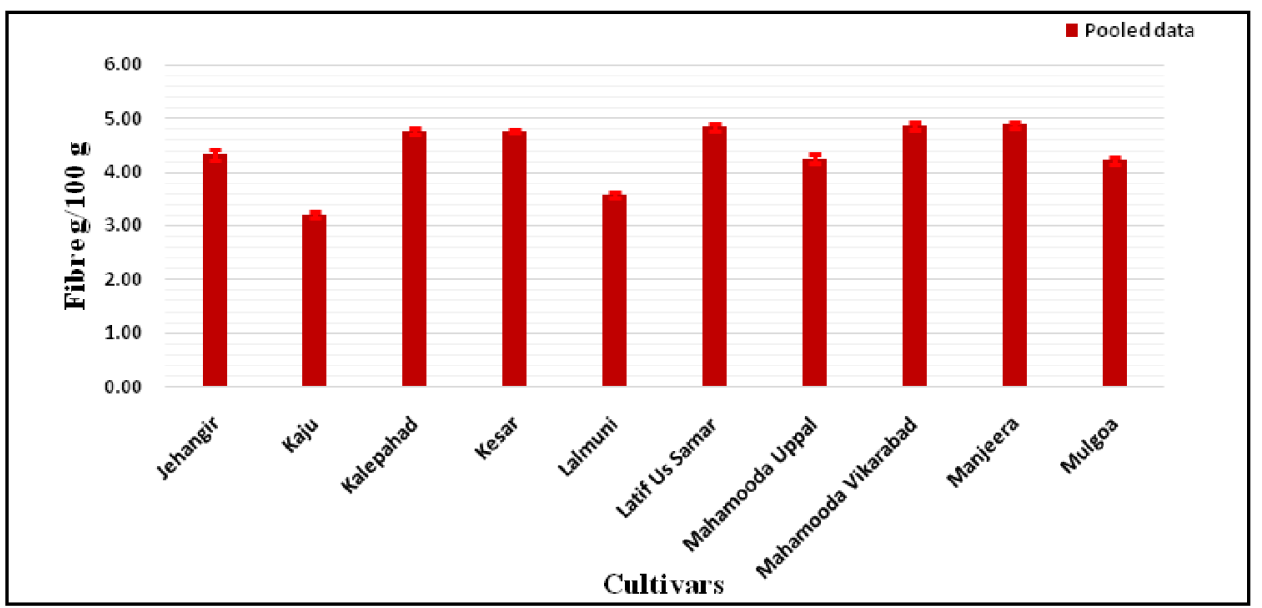

Figure 1(c): Crude fiber content $(\mathrm{g} / 100 \mathrm{~g})$ of ten mango (Table) cultivars

(Values are Mean \pm SD values of three replicates, $(\boldsymbol{p} \leq \mathbf{0 . 0 5}$, vertical bars indicate the error) 


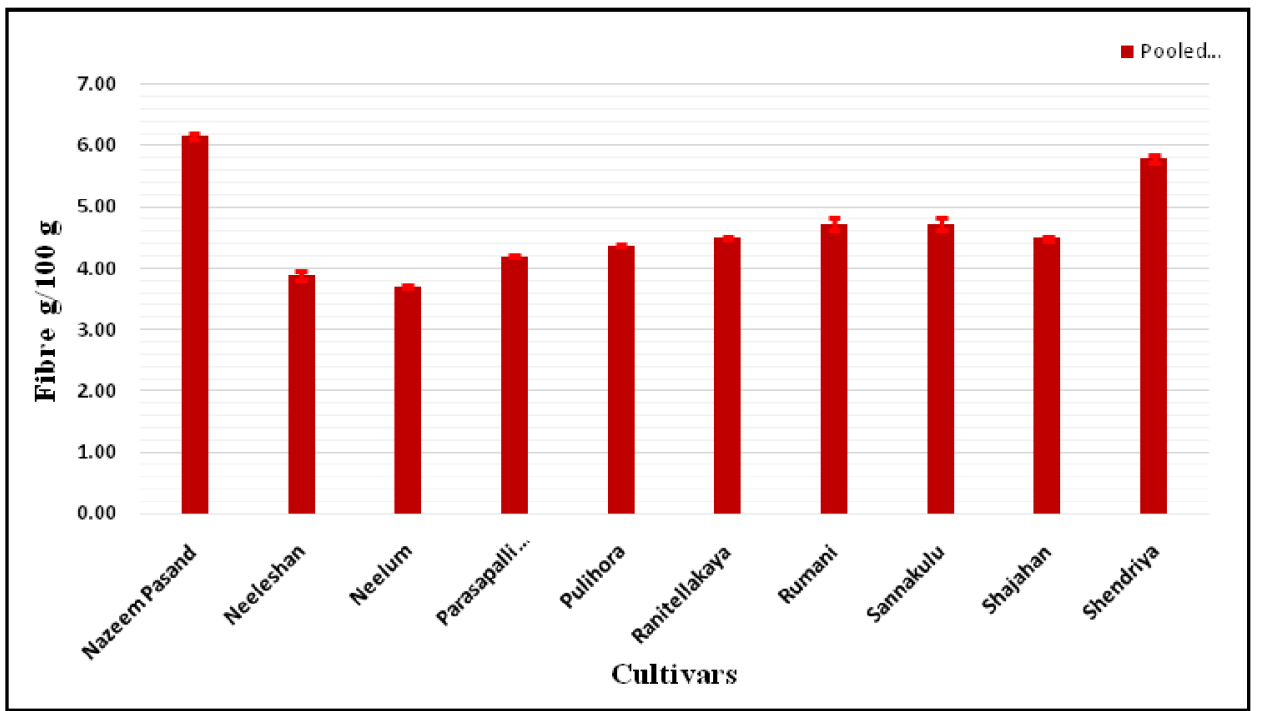

Figure 1(d): Crude fiber content (g/100 g) of ten mango (Table) cultivars.

(Values are Mean \pm SD values of three replicates, $(\boldsymbol{p} \leq \mathbf{0 . 0 5}$, vertical bars indicate the error) (Aryavartham Irsalu, Cherukurasam, Chinnarasam and Kothapalli Kobbari are juicy cultivars)

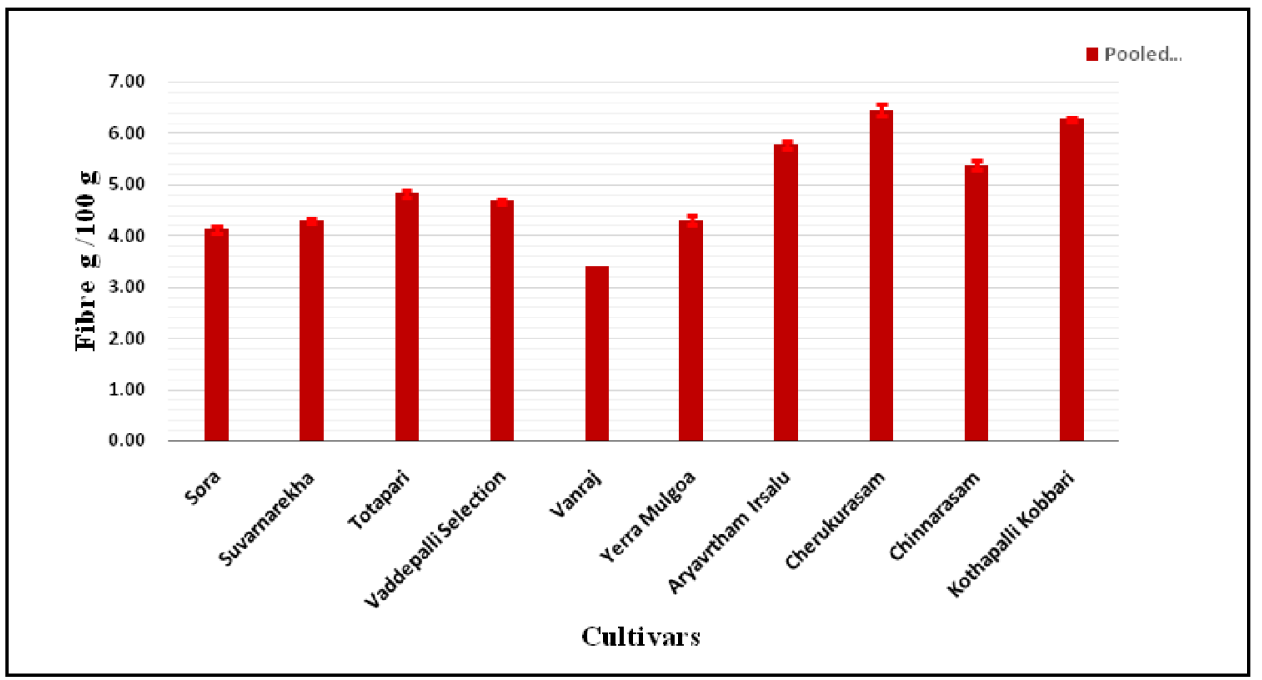

Figure 1(e): Crude fiber content (g/100 g) of ten mango (Juicy) cultivars.

(Values are Mean \pm SD values of three replicates, $(\boldsymbol{p} \leq \mathbf{0 . 0 5}$, vertical bars indicate the error)

Among the Juicy cultivars, significantly highest crude fibre amount was recorded in Nagulapalli Irsalu $(7.04 \mathrm{~g} / 100 \mathrm{~g})$, followed by Yellow Arati $(6.85 \mathrm{~g} / 100 \mathrm{~g})$ and Yerra Arati $(6.68 \mathrm{~g} / 100 \mathrm{~g})$, among the Table cultivars, Nazzem Pasand $(6.23 \mathrm{~g} / 100 \mathrm{~g})$ was recorded highest fibre amount during 2018-19.

During 2019-20, it was observed that, highest crude fibre amount was recorded in Nagulapalli Irsalu $(6.98 \mathrm{~g} / 100 \mathrm{~g})$, followed by Yerra Arati $(6.62 \mathrm{~g} / 100 \mathrm{~g})$ and Cherukurasam $(6.57 \mathrm{~g} / 100 \mathrm{~g})$. Among the Table cultivars, Nazzem Pasand (6.09 g/100 g) was recorded the highest fibre amount.

According to pooled data that the highest amount of crude fibre content was found in the Nagulapalli Iraslu $(7.01 \mathrm{~g} / 100 \mathrm{~g})$, followed by Yellow Arati $(6.53 \mathrm{~g} / 100 \mathrm{~g})$ and YerraArati $(6.65 \mathrm{~g} / 100 \mathrm{~g})$, among the Table cultivars, Nazzem Pasand $(6.16 \mathrm{~g} / 100 \mathrm{~g})$ was recorded the highest crude fibre amount. (Figures $1 \mathrm{c}$ and $1 \mathrm{e}$ ).
Mean results of both years, 2018 to $2019(4.89 \mathrm{~g} / 100 \mathrm{~g})$ and 2019 to $2020(4.88 \mathrm{~g} / 100 \mathrm{~g})$ and pooled data $(4.88 \mathrm{~g} / 100 \mathrm{~g})$ were on par with each other, because of environmental variation in the seasonal years.

\section{Discussion}

From the present results of mango cultivars, it is reported that the maximum amount of crude fibre content was recorded from the Juicy cultivars rather than the Table cultivars. Kothalawala and Jayasinghe (2017) reported that the maximum amount of crude fibre content was found in mango cultivars Karthakolomban (3.16 $\mathrm{gm} / 100 \mathrm{gm}$ ), followed by Gira Amba (2.06 gm/100 gm) and Bettiamba (1.98 gm/100 gm). The lowest amount of crude fiber was found in Willard $(1.17 \mathrm{gm} / 100 \mathrm{gm})$. Similar results were also reported by Ajila et al. (2007). They estimated the crude fibre content from the mango peels of Raspuri (Raw and Ripe) and Badami (Raw and Ripe) was found $1.16 \%$ to $3.0 \%$. 
Results reported from similar studies on crude fibre content of mango fruits by Abdul Rahman, (2013) (Drafur-Sudan); Othman and Mbogo, (2009) (Tanzania); Gopalan et al., (2000); Rathore, (2009) (India); Wenkam and Miller, (1965) (Hawaii) and Mamiro et al. (2007).

\section{Conclusion}

Based on the above investigations, it could be concluded that all fifty cultivars of mango that are grown popularly in Telangana State are rich and an adequate source of crude fibre content. From the results, the highest amount of crude fibre content was recorded in the Juicy cultivar, that is Nagiulapalli Iraslu and the lowest amount of crude fibre content was observed in the Table cultivar, Goa Bandar in both the years (2018-19 and 2019-20) as well as in pooled data. Among all the cultivars high fibre content was presented in the Juicy cultivars compared to Table cultivars. Finally, nutritional status of popular fitty mango varieties of Telangana State were estimated for the crude fibre content, which will help the consumers, dietitian and processing industry policy makers.

\section{Acknowledgements}

Authors gratefully acknowledge the financial support provided by Sri Konda Laxman Telangana State Horticultural University, College of Horticulture, Rajendranagar and also thankful to Fruit Research Station, Sangareddy for provision of experimental material.

\section{Conflict of interest}

The authors declare that there are no conflicts of interest relevant to this article.

\section{References}

Abdualrahman. (2013). Physicochemical characteristics of different types of mango (Mangifera indica L.) fruits in Drafur region and its use in jam processing. Science International, 1(5):144-147.

Abdullahi, M.B.; Tahir, F.; Shuaibu, A. and Wakili, A. (2010). Common medicinal plant species of Maladumba area, Misau, Bauchi States Nigeria. Int. J. Appl. Biol. Res., 2(2):102-109.
Ajila, C. and Bhat, Prasad Rao, U. J. S. (2007). Valuable components of raw and ripe peels from two Indian mango varieties. Food Chemistry. pp:1006-1011.

AOAC. (2000). Association of Official Analytical Chemists. Official methods of analysis, (Vol.II, 17th edition) of AOAC International, Washington DC, USA.

Berardini, N.; Matthias, Knödler; Andreas, Schieber. and Reinhold, Carle. (2005). Utilization of a mango peels as a source of pectin and polyphenolics. Innovative Food Science and Emerging Technologies, 6(4):442-452.

Gopalan, C.;Ramasastri, B.V. and Balasubramanian, S.C. (2010). Proximate principles: Common foods. In. B.S. Narasinga Rao, K.C. Pant, and Y.G. Deosthale (Eds.), Nutritive value of Indian foods (Revised and updated edition). (pp:5355). Hyderabad, India: National Institute of Nutition, ICMR.

Kim, Hana.; Moon, Jeo.; Kim, Hyeonji.; Lee, Dongsun.; Cho, Moonjae.; Choi, Hyung-Kyoon.; Kim, Young-Suk.; Mosaddik, Ashik and Cho, Somi. (2010). Antioxidant and antiproliferative activities of mango (Mangifera indica L.) flesh and peel. Food Chemistry. 121:429-436.

Kothalawala, S.G. and Jayasinghe, J.M.J.K. (2017). Nutritional evaluation of different mango varieties available in Sri Lanka. International Journal of Advanced Engineering Research and Science (IJAERS), 4(7):2349-6495.

Mamiro, P.; Fweja, L.; Chove, B.; Kinabo, J.; George, V. and Mtebe, K. (2007). Physical and chemical characteristics of off vine ripened mango (Mangifera indica L.) fruit (Dodo), Afri. J. Biotech., 6(21):2477-2483.

NHB. (2019). Indian Horticulture Database 2009, National Horticulture Board, Gurgaon, India.

Othman, O.C. and Mbago, G.P. (2009). Physicochemical characteristics of storage ripened mango (Mangifera indica L.) fruits varieties of Eastern Tanzania. Tanzania Journal of Science. 35:57-66.

Rathore, M.(2009). Nutrient content of important fruit trees from arid zone of Rajasthan. Journal of Horticulture and Forestry, 1(7):103-108.

Sagar, N.A.; Pareek, S.; Sharma, S.; Yahia, E.M. and Lobo, M.G. (2018). Fruit and vegetable waste: Bioactive compounds, their extraction, and possible utilization. Compr. Rev. Food Sci. Food Saf., 17:512-531.

Suparat, Sirisakulwat.; Andreas, Nagel.; Pittaya, Sruamsiri. and Reinhold, Carle. (2018). Yield and quality of pectins extractable from the peels of Thai Mango cultivars depending on fruit ripeness. Journal of Agricultural and Food Chemistry, 56(22):10727-38.

Wenkam, N.S. and Miller, C.D.(1965). Composition of Hawaii fruits. University of Hawaii, College of Tropical Agriculture, Hawaii Agricultural Experiment Station, Honolulu, Bulletin No. 135.

B. Soujanya, A. Kiran Kumar, A. Bhagwan, M. Sreedhar, S. Vanisri and P. Saidaiah (2021). Estimation of crude fiber 